\title{
Urban-Rural Relations in the Central Region of Mexico: A Viewpoint from Tlaxcala
}

\author{
Rocío Rosales Ortega
}

Rocio Rosales Ortega, Department of Sociology, Metropolitan Autonomous University-Iztapalapa, México (rro@xanum.uam.mx)

\begin{abstract}
During the 90's there was an important expansion of outsourcing industries all around the country and particularly on central region of Mexico, which enhanced an industrial diffusion that transformed the relation between rural an urban areas of the region. Labor and social practices around the textile industry on the region and particularly on the Tlaxcala state, enhanced the organization of a complex local-global network that was built on the context of the Nafta Agreement. Now a day, the local-global network around the textile industry has fall down due to the growing Chinese textile goods on the local and national market. The answer to this economic change has generated a wide range of changes among the different social actors that participated on the local-global network created by de textile industry during the golden years of the Nafta Agreement. Our research analyze the experience and strategies of a group of families from Tlaxcala, organized around the mixture of agricultural, manufacturing and service activities in order to reorganize the economic activities of their localities.
\end{abstract}

Keywords: industrial diffusion, family economic organization and industrial-rural relations

\section{Introduction}

During the decade of 1990, Mexico experienced an expansion of assembly plants (maquiladoras) and sub-contracting firms in the country's manufacturing industry, a tendency that was marked most clearly in the central region (see Map 1). ${ }^{1}$ This is one element that has contributed to the spread of a series of diffuse industrialization processes that the region had begun to experience in the preceding decade.

One feature that modified the ways of organizing work and the lifestyles of many of the inhabitants of the region's rural localities was the growing presence of those assembly plants, a process that expanded mainly during the boom period that followed upon the signing of the Free Trade Agreement (NAFTA). Now, in the early years of the $21^{\text {st }}$ century, the region's traditionally rural spaces have been transformed by a combination of agricultural, manufacturing and service activities, and become incorporated into the context of a region marked by the increasing integration of the economic sphere. Based on these antecedents, this study analyzes the organization of job markets in Tlaxcala, paying particular attention to the combination of economic activities and the process of the hybridization of those markets. It is based on three phases of fieldwork, the first of which took place in 1995-1999, when 35 questionnaires were applied at textile enterprises of different sizes. The second was carried out in 1999-2004, as 30 surveys were applied to small and medium enterprises. Finally, in 2008, several field visits and 18 interviews were carried out.

\footnotetext{
${ }^{1}$ Central Mexico includes Mexico City (the Federal District), the State of Mexico and the following states: Morelos, Hidalgo, Tlaxcala and Puebla.
} 
The first section presents an overview of debates and reflections that have emerged concerning the topic of urban-rural interrelations in the Mexican context. After that, the article elaborates a brief panorama of the key socio-economic characteristics of Mexico's central region and of Tlaxcala in particular, in order to better understand the historical context that has given rise to the combination of economic activities and the development of flexible manufacturing sectors such as a neo-artisanal textile industry. In the conclusions, we reflect on the overlapping of a city-region formation in the central region of Mexico with globalization processes.

\section{Urban-rural relations in a regional context}

Studies of urban and rural spaces have often been characterized by models that emphasize the contrasts between these two socio-territorial realities. In a reaction to this perspective in the 1990s, a new line of thought on rural development evolved under the name "the new rurality," (Arias, 2002; Ávila, 2001; De Grammont, 2004; Llambí, 1996; Long, 1996). This perspective recognized that rural spaces do not consist only of agricultural activities performed by dispersed populations. This territorial view of the so-called "rural sector" allows the integration of multiple, related functions including agriculture, agroindustrial and handicraft production, services, wage labor in small and medium-sized industries, tourism and culture, as well as the conservation of biodiversity and natural resources; thus incorporating life-sustaining local and global ecosystems and productive activities (Llambí, 1996).

One could speak of the appearance of pluri-activity and multi-functionality in the rural space because new economic opportunities have emerged and become the main source of income for inhabitants to such a degree, in some cases, that they are no longer considered complementary activities to agriculture or livestock-raising (Long, 1996). In summary, this "new rurality" was developed by specialists on rural areas who observed a new country-city relationship in which the borders between these two spheres of society were blurred while their interconnections had multiplied and become more complex (De Grammont, 2004).

Another perspective that refers to processes of urban-rural integration that have occurred in Mexico (Ávila 2001) revisits concepts such as "peri-urbanization" and "rurbanization" in order to reconstruct the reasoning behind them. The main argument here is that as cities grow they absorb rural areas and make them part of their periphery. The city-region concept has been adopted from the urban-regional approach, which includes other theoretical elements, such as conurbation, urban framework and urbanrural transition. This perspective starts out from an urban viewpoint, recognizing that large cities are not only capable of integrating their immediate metropolitan surroundings, but also that their economic and social dynamism can extend out and influence other cities with their own rural surroundings within a larger territorial extension; a process that leads to the formation of urban-regional networks (Scott, 2001; Healey, 2009).

In the case of the central region of México, the urban framework is constituted mainly by the capital cities of the states that surround Mexico City. As the entities that organize that territory, those cities generate diffuse experiences of urbanization and industrialization (Dematteis, 1998; Delgado, et al., 1999). Diffuse industrialization can be understood as a process through which large cities cease to act as poles of concentration for industrial activities and gradually become characterized by servicebased economies. This, in turn, makes it possible for other areas -mainly those around the cities- to become secondary sites, thus generating a diffused system of manufacturing activity (Escutia and Monroy, 2006). 
In this sense, the regional scale contributes to the study of urban-rural interrelations in two ways; first, by means of the functional study of what is urban and what is rural; ${ }^{2}$ and, second, because it becomes increasingly interested in analyzing the social and productive processes that generate the integration of these two socioterritorial realities. The concentration-dispersion processes of economic activities within a territory are two phenomena that manifest themselves in this epoch of global economic restructuring (Scott, 2001). This new stage not only favors mechanisms of concentration but, paradoxically, offers optimal conditions for the dispersion of economic activities through the creation of territorial networks. Here, it is the phenomenon of the urban-regional economy that reflects these new conditions (Delgado, et al., 1999; Pracedo, 2004).

According to Geyer and Kontuly (1996), medium and small cities enjoy certain advantages related to their functional organization that favor the dynamics of productive activities in a network-territory. These authors identify two kinds of networks in relation to medium and small cities. The first is called a "complementarity network" and is formed by cities, each of which has specialized functions that allow them to complement each other. These are regional city networks characterized by the territorial integration of all the elements involved in the regional system into a diffuse and integrated urban network. The second type of network is called "synergetic" or "associative". It consists of similar cities that establish cooperative relations among themselves that allow them to attain advantageous thresholds and, therefore, new competitive edges. These are spatially-separated, individual cities that come to be united by flows (of people, products, etc.), and that have a more open style of functioning, but that maintain a clear division from the surrounding territory.

An additional point that must be stressed is that these territorial networks contribute to integrating various localities, thus leaving behind dichotomy-based urbanrural viewpoints. They take a more flexible approach that includes concepts like complementarity and territorial equilibrium. In summary, the network-region system contributes to the analysis and comprehension of urban-rural relations as a product of the combination of various forms of socioeconomic organization (Pracedo, 2004). In addition, it is an effective means of analyzing processes of city-region formation and global economic restructuring because it sees them as two facets of the same reality.

\section{Mexico's central region and its recent transformations}

Two of the motors of the industrialization process and urbanization of the states that make up Mexico's central region were the series of industrial parks and urban programs implemented throughout the 1953-1996 period. ${ }^{3}$ The relocation of certain industries in the 1970s under the aegis of development policies was designed to spur industrial decentralization and decrease existing regional disparities created by the excessive concentration of economic activities and people in Mexico City. Those initiatives offered to establish infrastructure suitable for the relocation of those enterprises and propelled the process of outsourcing from both Mexico City and other regional urban centers (Rosales, 1999; Serrano 1996). This context favored the generation of an urban-regional economy in which small and medium cities and rural areas were re-organized as a function of changes in the economy in order to create increasingly complex networks of exchange and complementarity.

\footnotetext{
2 According to Mexico's demographic criteria, rural localities are defined as those having fewer than 2,500 inhabitants.

${ }^{3}$ Garza (1992) and Aguilar (1993) agree in considering industrial parks and urban programs as the most important regional planning instruments implemented by the Mexican state.
} 
It was in this framework that the formation of an urban-regional network based on a gravitational model of telephonic flows and the combination of sectorial economic activities was analyzed. More recently, in the decade of 1990, a study of the changes in migratory patterns in cities of different sizes in the central region was added ${ }^{4}$ (Galindo and Delgado, 2006).

Later, from the 90s onward, a growing diffusion of manufacturing assembly plants $^{5}$ and an increase in the number of second residences in the region's rural areas was observed, though these processes have only recently begun to be studied. With respect to the presence of industrial activities in rural localities, some advances have been made in statistical analyses, ${ }^{6}$ but field research based on case studies is the approach that has most successfully taken note of the arrival of both assembly plants and second residences in rural areas.

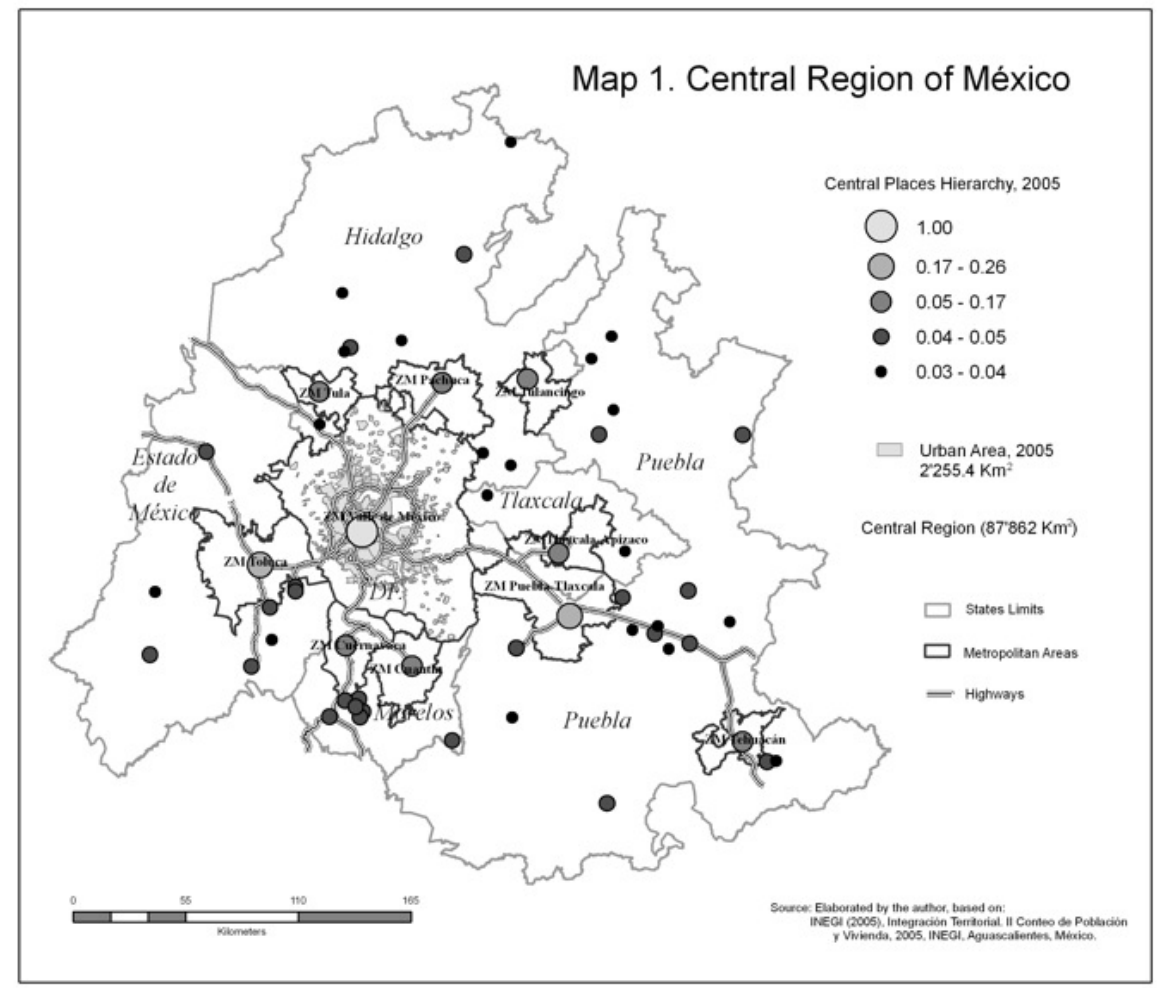

\footnotetext{
${ }^{4}$ With respect to migratory processes, the region appears to have experienced two important changes: first, a process that is occurring at the national level that consists in substituting the traditional country-city migration pattern with predominantly urban-urban or metropolitan-urban trajectories; and, second, in terms of immigration, states in the central region are strengthening their interdependencies while at the same time opening themselves up to more emigration and establishing more extensive connections with other regions of the country (Negrete, 1999).

${ }^{5}$ As a result of the signing of NAFTA (1994), Mexico became a favorable site for companies in the American fiber, textile, manufacturing and department store sectors that were looking to establish low-cost suppliers in nearby markets. This led the maquiladora sector to experience not only an important surge in Mexico, but also to modify its tendencies with respect to location, from the north of the country, which had predominated since the sixties, towards the central and southeastern parts of the country (Aguilar and MacLachlan, 1998; Quintero and De la O, 2001).

Wilson and Palacios (cited in Mediola, 1997:199) found two new relocation criteria for export assembly companies established in inland municipalities. The first, which has predominated, consists in establishing firms in large, relatively developed urban areas where external and more agglomerated economies are generated, rather than on Mexico's northern border. The second criterion includes choosing smaller, more isolated localities with scarce or non-existent infrastructure and weakly integrated economies that offer a particular advantage: plants installed there may become the area's principal -or only- employer of captive local labor.

${ }^{6}$ Galindo and Delgado's work (2006) is an important contribution to the process of constructing indicators that measure the rural-urban dynamics in localities in the country's central region. With regards to processes of rural industrialization they employ an industrial location quotient based on the region's most important manufacturing subsectors.
} 
Two concepts that add greater precision to the study of the diffusion of assembly plants in the country have been referred to as "rural industrialization" and "the new rusticity". The former is of a more quantitative character, while the latter leans towards qualitative descriptions of processes that include the incorporation of activities in the service sector. Delgado (2003) explains rural industrialization using what he calls the "industrial location quotient" in rural areas; while Arias (1992) holds that the "new rusticity" focuses on the new relations of production that diversify productive activities in the countryside (industry, outsourcing) when nearby medium-sized cities or metropolitan areas become integrated into production networks. Arias (2005) breaks down his proposal into analyses of the following features: a) how certain local groups confront the tendencies and metamorphoses associated with globalization; b) the ability to re-elaborate and readapt local trajectories according to the tendencies of the economy and markets; and, c) how groups succeed in redefining specializations and redesigning their spatial organization. Thus, the "new rusticity" is interested in the modalities of social organization that emerge with the penetration of new economic activities.

Table 1: The most dynamic manufacturing sub-sectors in the central region, 1986-1999 and 1999-2004

\begin{tabular}{|c|c|c|c|c|c|}
\hline & \multicolumn{5}{|c|}{$C E N T R A L R E G I O N$} \\
\hline $\begin{array}{l}\text { Manufacturing } \\
\text { industries } \\
\text { subsectors }\end{array}$ & $\begin{array}{c}\text { Working } \\
\text { population } \\
\text { occupied } \\
1986 \\
\end{array}$ & $\begin{array}{c}\text { Working } \\
\text { population } \\
\text { occupied } \\
1999 \\
\end{array}$ & $\begin{array}{c}\text { Working } \\
\text { population } \\
\text { occupied } \\
2004 \\
\end{array}$ & $\begin{array}{c}\begin{array}{c}\text { Rate of } \\
\text { growth } \\
1986-1999\end{array} \\
\end{array}$ & $\begin{array}{c}\begin{array}{c}\text { Rate of } \\
\text { growth }\end{array} \\
\text { 1999-2004 } \\
\end{array}$ \\
\hline Food, drink and tobacco & 176,479 & 246,272 & 260,319 & 2.60 & 1.11 \\
\hline $\begin{array}{l}\text { leather } \\
\text { Wood and wood }\end{array}$ & 197,917 & 349,899 & 281,859 & 4.48 & -4.23 \\
\hline $\begin{array}{l}\text { products, including } \\
\text { furniture } \\
\text { Paper and paper }\end{array}$ & 40,017 & 52,896 & 14,441 & 2.17 & -22.87 \\
\hline $\begin{array}{l}\text { products, printers and } \\
\text { publishers }\end{array}$ & 77,886 & 108,744 & 93,583 & 2.60 & -2.96 \\
\hline $\begin{array}{l}\text { Chemicals and products } \\
\text { derived from petroleum, } \\
\text { carbon, rubber and } \\
\text { nlastic }\end{array}$ & 190.909 & 221525 & 214345 & 115 & -0.66 \\
\hline $\begin{array}{l}\text { Non-metallic mineral } \\
\text { products, excluding } \\
\text { petroleum and carbon } \\
\text { derivatives }\end{array}$ & 59,534 & 64,816 & 62,470 & 0.66 & -0.73 \\
\hline Basic metal industries & 41,095 & 9,122 & 16,505 & -10.93 & 12.59 \\
\hline $\begin{array}{l}\text { Metal products, } \\
\text { machinery and } \\
\text { equipment, including } \\
\text { surgical and precision } \\
\text { instruments }\end{array}$ & 343,125 & 306,977 & 291,414 & -0.85 & -1.04 \\
\hline $\begin{array}{c}\text { Other manufacturing } \\
\text { industries }\end{array}$ & 15,624 & 23,281 & 44,476 & 3.12 & 13.82 \\
\hline $\begin{array}{l}\text { Manufacturing } \\
\text { industries }\end{array}$ & $1,142,586$ & $1,383,532$ & $1,279,403$ & 1.48 & -1.55 \\
\hline
\end{tabular}

Source: Galindo and Delgado, 2006:204

On the one hand, adopting a regional perspective helps to place both industrialization in general (driven by ISI government policies) and rural industrialization in particular (generated through the economic restructuring that took 
place in the 90s) into historical perspective. On the other, looking at local experiences allows us to better understand the overlapping of economic activities and the hybridization of labor markets, two topics that for too long have been analyzed separately.

In the quantitative perspective, indirect statistical information helps document the growing presence of rural industrialization in the central region as a whole. Table 1 provides an overview of the rate of change among the main activities of manufacturing companies. It is important to note that the textile-clothing-leather industrial subsector has occupied second place in the region and, moreover, that its growth tendencies can be related to the two most important stages observed during fieldwork. In the first stage of research (1995-1999), producers from companies of various sizes spoke of the high number of orders that had to be completed and delivered in order to cover U.S. demand generated by the marketers who requested their products. However, the fieldwork carried out from 1999 to 2004 revealed a much different situation, one marked by growing disappointment and discouragement among textile producers and manufacturers that included the closings of micro- and medium-sized businesses, due to the decrease in orders by marketers.

In order to analyze the processes of socioeconomic change experienced by the population, we also conducted a historical analysis of Tlaxcala, one of the states in the region, and held interviews with small and medium producers in the textile and manufacturing sectors. We considered that this was the most effective way of achieving a more precise understanding of the strategies adopted and the kinds of bonds that local populations formed in the context of changes on a global and regional scale.

\section{Tlaxcala: The reconfiguration of labor markets}

In colonial times, textile industrialization in the Puebla-Tlaxcala region was carried out mainly through the interrelation of textile plants and domestic suppliers, though the latter maintained a close interdependence between their agricultural production and participation in industrial activities. According to Miño (1999), textile plants and cottage industries together formed a proto-industrialization process ${ }^{7}$ that, in Heath's (1982) estimation slowed or perhaps even blocked industrial development in Tlaxcala.

The period of the Mexican Revolution would profoundly affect the economic life of the country and Tlaxcala was no exception. Recuperation took a long time and it was not until World War II that the country's textile sector recovered significantly. However, and despite this partial recovery, Tlaxcala was not successful in overcoming certain severe problems of economic development, though promoting the construction of industrial parks in the 1960s was intended to alleviate them, as one element in a series of policies designed to foster industrial decentralization that were promoted at the national level.

\footnotetext{
7 “...,the proto-industry and its concept is tied to the disperse rural production, whose dynamic was characterized by the interdependence between agriculture and industry, suggested by Mendels (Mendels, proto-industrialization, 1973). These elements make up the fundamental thesis: before the investment of manufacturing capital got to be dominant, it was substantial and determining in industrialization through the multiplication of domestic production units that had a modest capital available to them and were located in rural regions around the market centers" (Miño Grijalva, 1999:33, 38).
} 


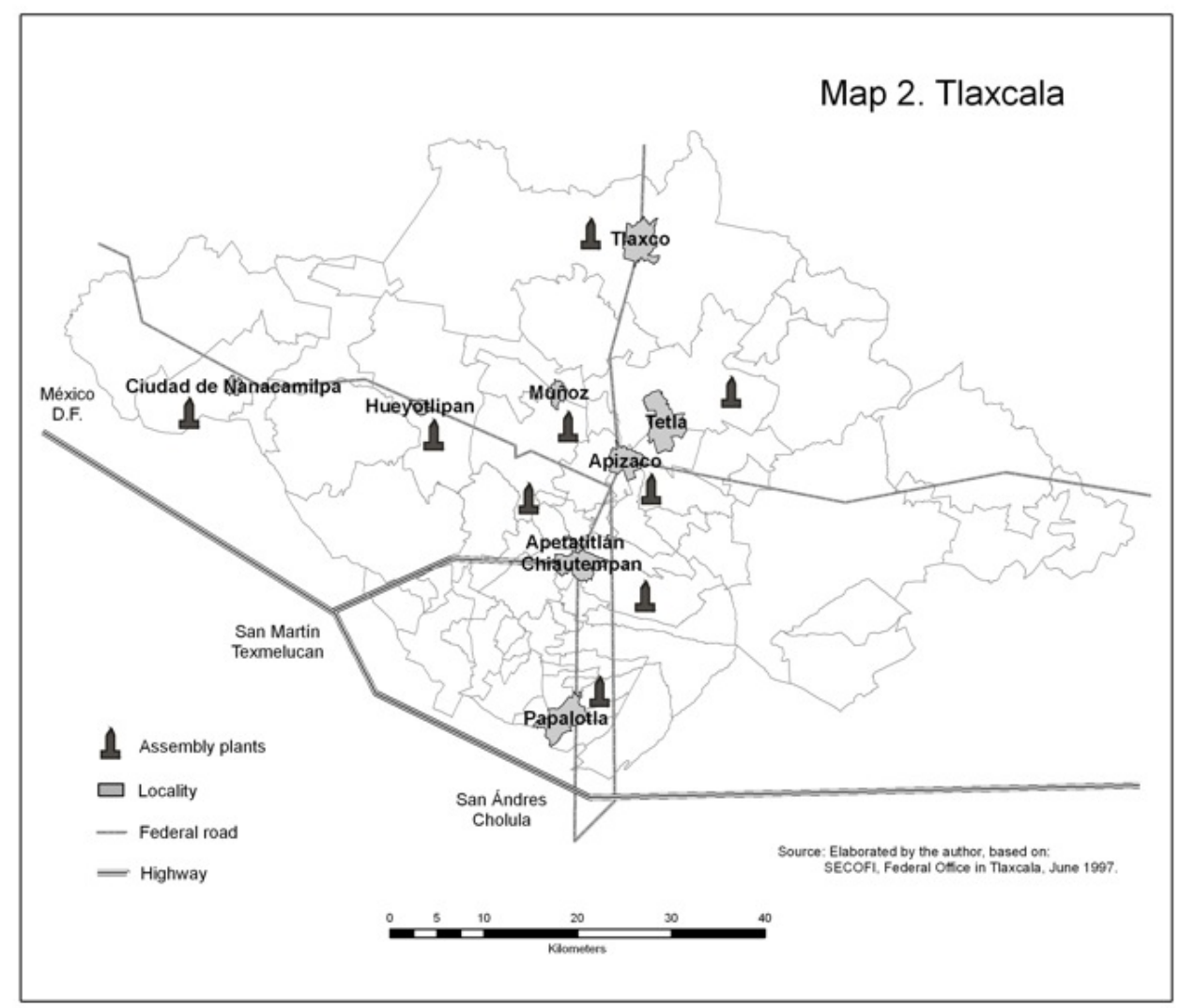

One example of the country-city interrelation in the state of Tlaxcala was observed at the outset of a process of industrialization in the municipality of Nanacamilpa, when Impulsora Industrial S.A. (a company that bought barley) convinced agricultural suppliers to abandon traditional crops and devote their fields to barley production. However, these and other changes in the organization of production failed to dislodge people from their land (Ramos, 1998).

By the 1990s, the emergent industrial structure was characterized by: 1) mass production factories that supplied national and international markets; 2) semi-industrial workshops that assembled products for larger national companies; and, 3) handicraft production destined for regional or international markets (Rendón, 1996). Turning to the experience of the municipality of Contla (Rosales, 2003), the situation that predominated in the 1990s, and continues today, involves combining agricultural activities with clothing or handicraft production. This paved the way for a flexible, variable scheme of territorial occupation in which the urban and rural spheres find themselves in a situation that oscillates between tension and economic complementarity.

The proliferation of textile and handicraft activities has been one way of maintaining the bonds between manufacturing and agricultural production, mainly because of the flexible model that this kind of production allows. Having tools in the home or running small workshops located nearby generates a favorable context for combining a series of different activities, all of which contribute to sustaining the rural economy. Textile production in small capitalist-oriented factories is also integrated into this mix of economic activities. However, the working conditions in which rural laborers are ensconced tend to be unstable because those factories usually employ people from the surrounding countryside who remain in their hometowns, work for low wages, and enjoy a certain flexibility; i.e., given the unstable nature of employment conditions, they accept being hired and laid off without much fuss (Arias, 2002). 
The organization of textile production has encouraged intraregional mobility by the workforce, making this one of the defining characteristics of the socio-economic dynamics of the state of Tlaxcala. Traditionally, a significant part of the population of rural origin has moved daily from their place of residence to larger urban centers like Tlaxcala, Santa Ana Chiautempan and Apizaco, where the main industries that offer employment are located. These municipalities have also absorbed flows of internal migration; however, the deep attachment that rural workers so often feel towards their land often lead migrant populations to approach the cities where employment as industrial wage-workers makes it possible for them to conserve their bonds with their hometowns (Heath, 1982).

In the context of a series of crises in Tlaxcalan agriculture, heads of households have found themselves obliged to complement family income with handicraft work or wage labor in textile factories. However, the instability of the textile sector has also contributed to keeping them on their lands, since small-scale agricultural production allows the population to ensure family subsistence during difficult times.

The short distances between suburbanized municipalities and the city of Tlaxcala, together with a broad network of road infrastructure that functionally connects the urban centers and suburbs (see Map 2), have allowed mobility to become an everyday phenomenon, often related to work activities. It is very common for people to maintain their place of residence in municipalities like Santa Ana Chiautempan, Contla and San Pablo Apetatitlan, while commuting daily to some other place for work, thus creating daily itineraries that involve extensive spatial mobility.

Another kind of displacement is that carried out by people who reside in the downtown area or the periphery of small cities and commute to more important urban downtown areas in the central region of Mexico, mainly in the cities of Puebla, Toluca and Mexico City. Some of them are textile producers or intermediaries who market their merchandise in those metropolitan settings, while others have become incorporated into the labor markets that those metropolises offer.

The accelerated urbanization process in which both the state capital and its suburbanized municipalities are involved has led to various transformations. In the case of economic processes, we would underline the importance that the service industry has acquired in the economic dynamics of these small cities. Services are now an important source of employment for people in Tlaxcala, while commercial activities have also achieved great importance.

In this new scenario, micro and small producers, as well as workers, are all adapting to change. One strategy adopted by producers in Chiautempan and Apetatitán is to establish a store or shop in the same physical location as their main business or trade. Though this is by no means a recent phenomenon, the difference is that now they not only offer their own products, but may also sell the finished merchandise of other small producers from nearby municipalities. This is the case, for example, of Contla, which is now well known for its conservation of handicraft production. The networks that such operators establish with other small businessmen are what sustain the economic activity of the municipalities studied, by making it possible for them to purchase merchandise at lower prices and thus revitalize their local economies.

Though the economic situation today is not particularly propitious for establishing enterprises, some micro-producers from Apetatitlán have not only organized new ways of diversifying their production, locales and distribution networks, but have also shown interest in entering other areas of economic activity, distinct from textile manufacturing and production. Their goal, of course, is to obtain greater 
economic benefits. One example of this is a productive project being developed in the municipality of Apetatitlán that is based on the cultivation and marketing of orchids.

\section{Final considerations}

The processes of territorial and economic reorganization promoted by globalization have contributed to a rethinking of the rural-urban dichotomy and of the region as a flexible territorial environment. Concepts such as the new rurality, rurbanization, rural industrialization and the new rusticity have all been discussed as means of explaining recent transformations in country-city interrelations. In the same vein, the city-region concept has contributed by incorporating scalar analysis and the economic transformations that have taken place in Mexico's central region in different historical moments.

The history of economic development on the local scale, as in the case of Tlaxcala, indicates that the combining of economic activities has characterized economic dynamics. Due primarily to the frequent crises that have affected both the textile industry and agricultural production people have opted to complement family incomes by participating in wage labor in a variety of economic sectors.

Differences in the strategies for combining economic activities appear to be due exclusively to the specific situations and circumstances that at any given time may bestow greater importance on one or another of a series of economic activity. For this reason people in Tlaxcala have combined an ongoing activity (like agricultural production) with more fluctuating work opportunities, such as wage labor in assembly plants, or employment in the service sector. Tendencies in long-term economic transformations, such as the change from manufacturing activities to outsourcing, have combined with processes on a shorter time frame, but linked on a global scale. This is the case of the production chains in the manufacturing industry that experienced a boom in the years from 1994 to 2000 .

There, when demand from American businesses showed signs of slowing down, people continued to work in the traditional activities that they pursued previously, perhaps on a lesser scale and with less demand and, very probably, in combination with service activities like commerce in different expressions, be they formal (as business owners or merchants in shopping centers), or informal, (small, in-home grocery stores, or as street vendors dispensing a wide variety of articles), depending upon their capacity for savings and investment.

\section{References}

Aguilar, I. (1993) Decentralización industrial y desarrollo regional en México. Una evaluación del programa de parques y ciudades industriales, 1970-1986, El Colegio de México.

Aguilar, M.A.G. and MacLachlan, I. (1998) "Maquiladora Myths; Locational and Structural Change in Mexico's Export Manufacturing Industry", Professional Geographer, 50 (3), pp. 315-331.

Arias, P. (1992) Nueva rusticidad mexicana. Mexico: Consejo Nacional de Ciencias y Artes.

Arias, P. (2002). "Hacia el espacio rural-urbano; una revisión de la relación entre el campo y la ciudad en la antropología social mexicana", Estudios Demográficos y Urbanos, mayo-agosto, no. 50, El Colegio de México, Mexico, 363-380.

Arias, P. (2005) "Nueva ruralidad: Antropólogos y geógrafos frente al campo hoy", in, H. Ávila Sánchez (coord.) Lo urbano-rural ¿nuevas expresiones territoriales?, 
UNAM, Centro Regional de Investigaciones Multidisciplinarias, Cuernavaca, Morelos, pp. 123-160.

Ávila, H. (2001) "Ideas y planteamientos teóricos sobre los territorios periurbanos. Las relaciones campo-ciudad en algunos países de Europa y América", Boletín de Investigaciones Geográficas, Instituto de Geografía, UNAM, No. 45, Mexico, pp. 108-127.

De Grammont, H. (2004) "La nueva ruralidad en América Latina", Revista Mexicana de Sociología, año 66, Mexico, pp. 279-300.

Delgado, J., Larralde A. and Anzaldo, C. (1999) "Mexico City: Towards the Formation of a City-region", in A.G. Aguilar and I. Escamilla, Problems of Megacities: Social Inequalities, Environmental Risk and Urban Governance, UNAM, Institute of Geography, Mexico, Commission of Urban Development and Urban Life, IGU, pp. 599-611.

Delgado, J. (2003), "Transición rural-urbana y oposición campo-ciudad", in Adrián Guillermo Aguilar (coord.), Urbanización, cambio tecnológico y costo social. El caso de la región centro de México, UNAM, Instituto de Geografía, CONACYT and Miguel Ángel Porrúa, Mexico, pp. 73-118.

Dematteis, G., (1998), "Suburbanización y periurbanización. Ciudades anglosajonas y ciudades latinas", in Javier Monclús (ed.), La ciudad dispersa: suburbanización y nuevas periferias, Barcelona, Centre de Cultura Contemporania de Barcelona, pp. 17-33.

Escutia, R. and Monroy, F. (2006), "Industrialización difusa y complejos industriales en zonas rurales. El caso de IUSA en un municipio de Jocotitlán, Estado de México", Quivera, Revista de estudios urbanos, regionales, territoriales, ambientales y sociales, julio-diciembre, vol. 8, no. 002, Universidad Autónoma del Estado de México, Toluca, Mexico, pp. 184-208.

Garza, G. (1992), Desconcentración, tecnología y localización industrial en México. Los parques y ciudades industriales, 1953-1988, El Colegio de México.

Galindo C. and J. Delgado (2006), "Los espacios emergentes de la dinámica ruralurbana", Problemas del Desarrollo, Revista Latinoamericana de Economía, Vol. 37, no. 147, octubre-diciembre, UNAM, Instituto de Investigaciones Económicas, Mexico, pp. 187-216.

Geyer, H.S. and T.M. Kontuly, (eds.) (1996), Differential Urbanization. Integrating Spatial Models, Arnold, Great Britain.

Healey, P. (2009), "City Region and Place Development”, Regional Studies, 43 (6), pp. 831-843.

Heath Constable, H. J. (1982), Lucha de clases: La industria textil en Tlaxcala, Ediciones Caballito.

Llambí, L., (1996) "Globalización y nueva ruralidad en América Latina. Una agenda teórica y de investigación", in Sara Ma. Lara Flores and Michelle Chauvet (coords.), La inserción de la agricultura mexicana en la economía mundial, Vol. I, INAH, UAM, UNAM and Plaza y Valdés Editores, Mexico, pp. 75-98

Long, N., (1996) "Globalización y localización: nuevos retos para la investigación rural", in Sara Ma. Lara Flores and Michelle Chauvet (coords.), La inserción de la agricultura mexicana en la economía mundial, Vol. I, INAH, UAM, UNAM and Plaza y Valdés Editores, México, pp. 35-74.

Mendiola, P. G. (1997)," "Las empresas maquiladoras de exportación 1980-1995", in Dussel P., Michael P. and C. Ruiz Durán, Pensar globalmente y actuar regionalmente. Hacia un nuevo paradigma industrial para el siglo XXI, UNAM, Fundación Friedrich Ebert and Editorial Jus, Mexico, pp. 185-226. 
Miño Grijalva, M. (1999), “Protoindustria colonial?”, in Gómez-Galvarrieto, Aurora (coord.), La industria textil en México, Instituto José María Luis Mora, pp. 3152.

Negrete, M. E. (1999), “Desconcentración poblacional en la Región Centro de México", Estudios Demográficos y Urbanos, vol. 14, no. 2, mayo-agosto, pp. 313-352.

Precedo Ledo, A. (2004) Nuevas realidades territoriales para el siglo XXI. Desarrollo local, identidad territorial y ciudad difusa, Editorial Síntesis, Madrid.

Quintero C. and De la O M.E., (2001), (coords.) Globalización, trabajo y maquilas: Las nuevas y viejas fronteras en México, Mexico, Friedrich Ebert Stiftung, CIESAS, Plaza y Valdez Editores.

Ramos Galicia, S. (1998), Tlaxcala: 1960-1980, Monografía histórica, Mexico.

Rendón Garcini, R. (1996), Breve historia de Tlaxcala, FCE and El Colegio de México.

Rosales Ortega, R. (1999), "Transformaciones territoriales y perspectivas de desarrollo regional mediante la pequeña industria", in Javier Delgado and Blanca Ramírez (coords.), Territorio y cultura en la ciudad de México, Tomo I, Transiciones, Plaza y Valdez Editores, Mexico, pp. 83-102

Rosales Ortega, R. (2003), “Tlaxcala, ¿un distrito industrial?”, Sociológica, enero-abril, V. 18, no. 51, Universidad Autónoma Metropolitana, Mexico, pp. 131-163.

Scott, A.J (ed.) (2001), Global City-Regions. Trends, Theory, Policy. London, Oxford University Press.

Serrano Moreno, J. R. (1996), "De la periferia hacia el Centro (o el rescate del la unidad: los estados circundantes ante la ciudad de México)”, in Serrano Moreno, J. R. (coord.), De Frente a la ciudad de México. ¿El despertar de los estados que la circundan?, Vol. I, UNAM and Universidad Autónoma de Querétaro, pp. 272286. 